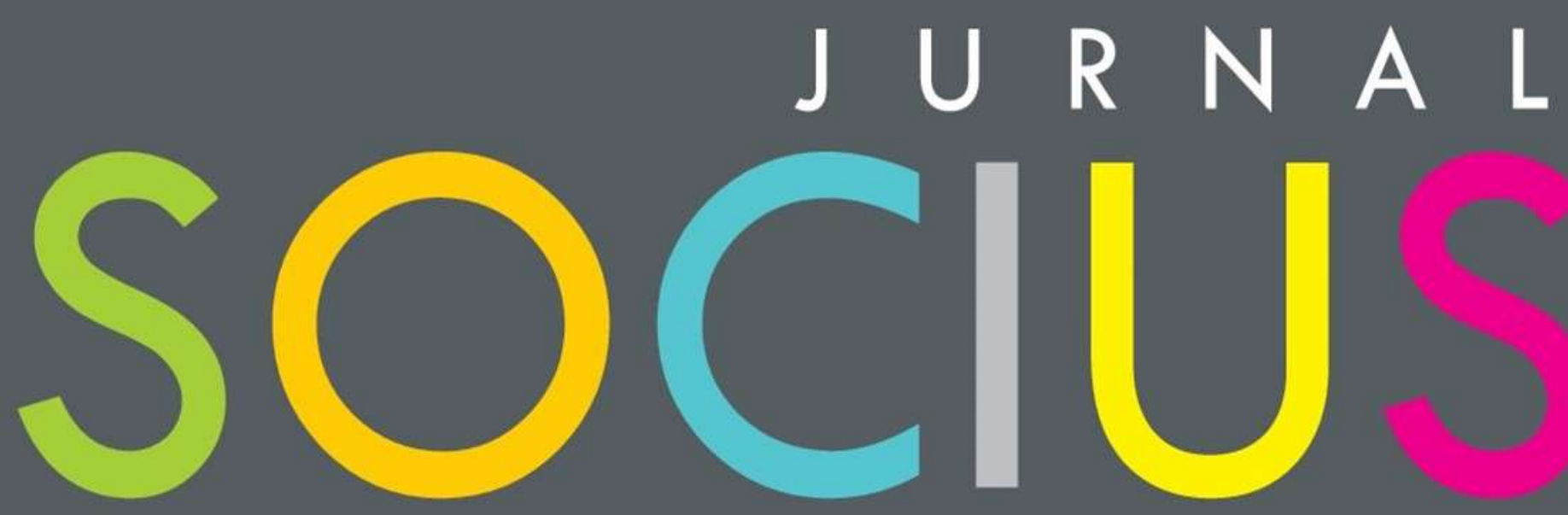

Journal of Sociology Research and Education

DITERBITKAN OLEH :

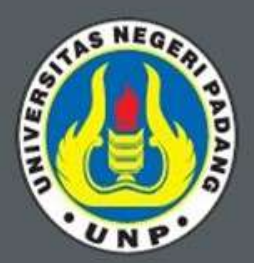

LABOR

JURUSAN SOSIOLOGI

FAKULTAS ILMU SOSIAL

UNIVERSITAS NEGERI PADANG

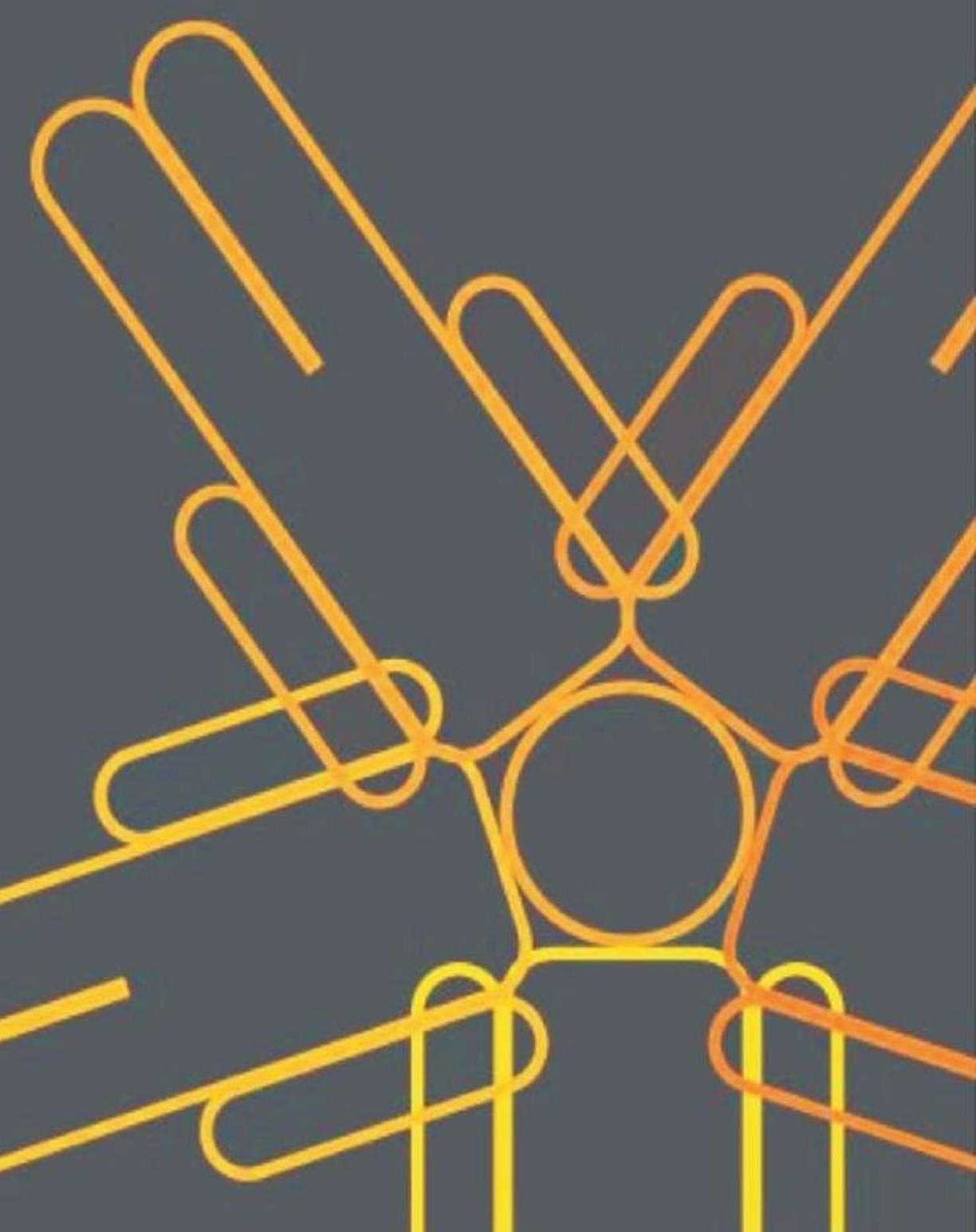




\section{SOCIUS}

Vol. 8, No. 1, Th. 2021

ISSN : 2356-4180 (cetak)

2442-8663 (online)

\begin{tabular}{|c|c|}
\hline $\begin{array}{c}\text { REDAKSI } \\
\text { JURNAL SOCIUS }\end{array}$ & DAFTAR ISI \\
\hline $\begin{array}{l}\text { Editor in Chief : } \\
\text { Desy Mardhiah } \\
\text { (Universitas Negeri Padang) }\end{array}$ & $\begin{array}{c}\text { Arni Darmayanti, Gede Budarsa } \\
\text { Peran Ganda Perempuan Bali di Masa Pandemi Covid-19 } \\
\text { Halaman } 1-12\end{array}$ \\
\hline $\begin{array}{l}\text { Managing Editor : } \\
\text { Erda Fitriani } \\
\text { (Universitas Negeri Padang) }\end{array}$ & $\begin{array}{c}\text { Luthfi Hasanal Bolqiah, Riaty Raffiuddin } \\
\text { Dominasi Oligarki dalam Pembangunan Reklamasi Pantai Utara Jakarta } \\
\text { Halaman 13-25 }\end{array}$ \\
\hline $\begin{array}{c}\text { Editorial Board: } \\
\text { Elfitra Baikoeni } \\
\text { (Universitas Andalas) }\end{array}$ & $\begin{array}{c}\text { Rinel Fitlayeni, Ikhsan Muharma Putra, Marleni Marleni, } \\
\text { Elvawati Elvawati, Winda Sri Yulia Putri }\end{array}$ \\
\hline $\begin{array}{c}\text { Iskandar } \\
\text { (Universitas Trunojoyo) }\end{array}$ & $\begin{array}{c}\text { Penguatan Kapasitas Pedagang dalam Resolusi Konflik Asimetris di } \\
\text { Pasar Raya Padang Pasca Gempa }\end{array}$ \\
\hline $\begin{array}{c}\text { Ike Sylvia } \\
\text { (Universitas Negeri Padang) }\end{array}$ & Halaman $26-35$ \\
\hline $\begin{array}{c}\text { Erianjoni } \\
\text { (Universitas Negeri Padang) } \\
\text { Emizal Amri } \\
\text { (Universitas Negeri Padang) }\end{array}$ & $\begin{array}{c}\text { Dahlia Morina Hutagalung, Ferdinand Kerebungu, Maryam } \\
\text { Lamadirisi } \\
\text { Perilaku Belajar Mahasiswa Batak Toba di Universitas Negeri Manado } \\
\text { Halaman 36-46 }\end{array}$ \\
\hline $\begin{array}{l}\text { Mohammad Isa Gautama } \\
\text { (Universitas Negeri Padang) }\end{array}$ & $\begin{array}{c}\text { Rifqi Asy'ari, Rusdin Tahir, Cecep Ucu Rakhman, Rifki } \\
\text { Rahmanda Putra }\end{array}$ \\
\hline $\begin{array}{l}\text { Khairul Fahmi } \\
\text { (Universitas Negeri Padang) }\end{array}$ & $\begin{array}{l}\text { Pengembangan Pariwisata Berbasis Masyarakat di Provinsi Jawa Barat } \\
\text { Halaman 47-58 }\end{array}$ \\
\hline $\begin{array}{c}\text { Reno Fernandes } \\
\text { (Universitas Negeri Padang) }\end{array}$ & $\begin{array}{c}\text { Reno Fernandes, Azwar Ananda, Maria Montessori, Firman } \\
\text { Firman, Eka Vidya Putra, Hendra Naldi, Erda Fitriani }\end{array}$ \\
\hline $\begin{array}{l}\text { Layout Editor : } \\
\text { Rhavy Ferdyan } \\
\text { Technical Support: } \\
\text { Rudi Mahesa }\end{array}$ & $\begin{array}{c}\text { Adaptasi Dosen Digital Immigrant Terhadap Pelaksanaan Pembelajaran } \\
\text { pada Masa Pandemi Covid-19 } \\
\text { Halaman 59-72 }\end{array}$ \\
\hline $\begin{array}{c}\text { Alamat Redaksi: } \\
\text { Jurusan Sosiologi FIS UNP } \\
\text { Jl. Prof.Dr.Hamka } \\
\text { Kampus UNP Air Tawar } \\
\text { e-mail: socius@ @ppj.unp.ac.id }\end{array}$ & \\
\hline $\begin{array}{c}\text { Penerbit } \\
\text { Labor Jurusan Sosiologi } \\
\text { Universitas Negeri Padang }\end{array}$ & \\
\hline
\end{tabular}




\title{
Dominasi Oligarki dalam Pembangunan Reklamasi Pantai Utara Jakarta
}

\author{
Luthfi Hasanal Bolqiah ${ }^{1}$, Riaty Raffiuddin ${ }^{2}$ \\ ${ }_{1,2}$ Universitas Indonesia \\ Email: $\underline{\text { luthfi.hasanalbolqiah@gmail.com, riatyraf@gmail.com }}$
}

\begin{abstract}
Abstrak
Pengelolaan sumber daya alam di Indonesia berkontribusi sebesar 1.480,04 atau 10,89\% dari total keuntungan PDB Indonesia tahun 2017. Tetapi pada saat yang sama pengelolaan sumber daya alam juga menyumbang terhadap kerugian negara. Para teoritis seperti Richard Robison, Vedi R. Hadiz dan Jeffrey Winters memandang dominasi segelintir orang atau oligarki dengan berlebihan, sebaliknya dominasi material dari oligarki juga kurang mendapat perhatian teoritis pluralis seperti Marcus Mietzner, Michael Buehler, Michele Ford dan yang lainnya. Artikel ini berupaya untuk menganalisa oligarki dan ancaman terhadap oligarki pada satu kasus secara bersamaan yakni pembangunan Reklamasi Pantura Jakarta dengan kerangka teori dari Winters (2011). Dalam mengumpulkan data, penelitian ini menggunakan metode kualitatif, dengan cara mengumpulkan data primer melalui wawancara mendalam dan kajian literatur. Hasil penelitian menunjukkan bahwa dominasi oligarki dimulai pada pembangunan Reklamasi Pantai pantura sejak dari era kepemimpinan Soeharto. Sedangkan pada masa reformasi, oligarki menjali hubungan dengan kepala daerah atau dalam hal ini Gubernur DKI Jakarta untuk mempertahankan dominasi oligarki. Namun selain itu, terdapat juga oligarki atau aktor lain yang ikut serta pada masa reformasi dengan mengambil alih perusahaan yang sebelumnya sudah mendapatkan izin pembangunan.
\end{abstract}

Kata kunci: Dominasi Oligarki, Elit Pemerintah, Pembangunan Ekonomi-Politik, Reklamasi Pantai Utara Jakarta

\begin{abstract}
Natural resource management in Indonesia contributed 1,480.04 or $10.89 \%$ of Indonesia's total GDP profit in 2017. But at the same time, natural resource management also contributed to state losses. Theorists such as Richard Robison, Vedi R. Hadiz, and Jeffrey Winters view the dominance of a handful of people or oligarchy excessively, on the other hand, the material domination of the oligarchy has also received less attention from pluralist theorists such as Marcus Mietzner, Michael Buehler, Michele Ford, and others. This article attempts to analyze oligarchy and threats to oligarchy in one case simultaneously, namely the construction of the Jakarta Coastal Reclamation with the theoretical framework of Winters (2011). In collecting data, this study used qualitative methods, by collecting primary data through in-depth interviews and literature review. The results showed that the dominance of the oligarchs began in the development of the northern coast reclamation since the Soeharto era. Meanwhile, during the reformation period, the oligarchs had a relationship with the regional heads or in this case the Governor of DKI Jakarta to maintain the dominance of the oligarchs. But apart from that, there are also oligarchs or other actors who participated in the reform period by taking over companies that previously had obtained development permits.
\end{abstract}

Keyword: Oligarchy Domination, Government Elites, Economic-Political Development, Jakarta
North Coast Reclamation

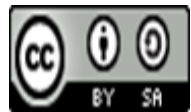

Received: October 24, 2020

Revised: June 10, 2021

Available Online: June 13, 2021

Jurnal Socius: Journal of Sociology Research and Education Vol. 8, No. 1, Th. 2021 


\section{Pendahuluan}

Persoalan pembangunan politik telah banyak dikaji oleh sejumlah ilmuwan, berikut kaitannya dengan pembangunan ekonomi (Huntington \& Fukuyama, 2006; Pye, 1966) atau spesifik terkait dengan sumber daya alam sebagai bahan produksi dan pendukung kehidupan (Barbier, 2003). Berdasarkan laporan KPK dalam Nota Sintesis tahun 2018 menyebutkan bahwa pengelolaan sumber daya alam berperan besar terhadap pemasukan Produk Domestik Bruto (PDB) yakni sebesar 1.480,04 Triliun atau 10,89\% dari total keuntungan PDB Indonesia tahun 2017. Di sisi lain, berdasarkan laporan The Club of Rome yang berjudul "The Limit of Growth" (1972) pengelolaan sumber daya alam yang berorientasi pada pertumbuhan ekonomi selain berdampak pada kerusakan lingkungan juga menghasilkan stagnasi ekonomi (Meadows, Meadows, Randers, \& Behrens, 1972).

Dampak negatif dari pengelolaan sumber daya alam di Indonesia selain stagnasi ekonomi juga berpotensi menyumbang terhadap kerugian negara. Menurut Koordinator Divisi Hukum dan Monitoring Peradilan Indonesia Corruption Watch (ICW), Tama S Langkun, dalam kurun waktu 2010-2017 sekurang-kurangnya terdapat 115 kasus korupsi dan 326 orang menjadi tersangka dalam perkara korupsi sumber daya alam, diantaranya dari sektor perkebunan, kehutanan dan pertambangan. Enam kasus saja, menurut Tama, memiliki potensi kerugian negara sebesar 7,26 Triliun (CNN Indonesia, 2018). Selain itu, Komisi Pemberantasan Korupsi (KPK) juga menetapkan Bupati Kota Waringin Timur Supian Hadi (5,8 Triliun), Mantan Gubernur Sulawesi Tenggara Nur Alam (2,78 T) dan Mantan Bupati Konawe Utara Aswa Sulaiman (2,7 Triliun) sebagai tersangka. Sedangkan dalam Nota Sintesis Hasil Evaluasi Gerakan Nasional Penyelamatan Sumber Daya Alam (GNP-SDA) tahun 2018, KPK menunjukkan bahwa dari 950 kasus yang ditangani semenjak 2004-2019, diantaranya 613 adalah penyuapan yang melibatkan banyak sejumlah instansi negara. KPK juga juga menyebut adanya peranan "institusi alternatif" (pseudo legal) yakni, "segelintir kelompok yang memiliki gurita penguasaan sistem dan struktur kuasa (sosial, ekonomi dan politik) yang kuat mampu meraup ragam keuntungan dengan cara-cara sistemik"(KPK RI, 2019).

Berdasarkan analisis KPK, pseudo legal merupakan jaringan yang dipelihara oleh kekuasaan, yang secara de facto lebih besar dari kekuasaan legal negara. Senada dengan itu, salah satu akar utama korupsi di Indonesia adalah sistem politik yang korup dan partai politik kartel (Bachtiar, Bolqiah, \& Andrean, 2020) yang dikendalikan oleh oligarki (Syarif \& Faisal, 2019). Adapun komitmen anti-korupsi pada era kepemimpinan Joko Widodo kurang mendapat perhatian karena target pembangunan ekonomi yang mensyaratkan stabilitas sosial-politik (Umam, 2019). Dominasi segelintir orang (dominated-minority) atas penguasaan sumber daya alam seharusnya tidak terjadi karena negara dalam hal ini pemerintah ikut serta mengatur pengelolaan sumber daya alam. Misalnya melalui UU No. 32/2009 tentang Perlindungan dan Pengelolaan Lingkungan Hidup (UUPPLH) dan Peraturan Menteri Negara Lingkungan Hidup No. 5/2012 tentang Jenis Rencana Usaha dan/atau Kegiatan Yang Wajib Dilengkapi Dengan Analisis Dampak Lingkungan Hidup (AMDAL), serta aturan lainnya yang dimaksudkan untuk mendistribusi dan meredistribusi sumber daya alam.

Kondisi demikian menunjukkan ketidaksesuaian analisis konstitusional dan institusional dalam menjelaskan persoalan dominasi segelintir orang atas penguasaan sumber daya alam di Indonesia. Hal itu disebabkan oleh kepentingan ekonomi dan politik seringkali beriringan, bahkan sukar untuk dipisahkan. Beberapa tulisan mengkaji fenomena penguasaan sumber daya alam, misalnya merujuk pada "orang kuat lokal" (Migdal, 1988), "bosissme" (Sidel, 2004), "rentier" (Beblawi \& Luciani, 2015) atau "oligarki" (Robison, 1986; Winters, 2011). Aktor- 
aktor tersebut memperkaya dirinya melalui kedekatan dengan elit politik atau terlibat langsung dalam proses politik untuk mendapatkan akses terhadap sumber daya alam.

Dampak dari aktor-aktor tersebut selain menyebabkan kegagalan pembangunan ekonomi dan kerusakan lingkungan, juga memperlebar ketimpangan materi. Meskipun demikian, para teoritis berfokus pada ketimpangan material sebagai konsekuensi logis keberadaan oligarki (Winters, 2011, 2014) dan sedikit sekali menaruh perhatiannya terhadap konsentrasi penguasaan sumber daya alam dan pembangunan politik (Hadiz \& Robison, 2013; Robison, 1986). Menurut Thomas B. Pepinsky tipologi oligarki yang dikemukakan Winters tidak dapat digunakan untuk mengklaim kausalitas tentang konsekuensi oligarki terhadap kebijakan dan hasil politik (Pepinsky, 2014). Adapun tulisan penelitian Buehler menganalisa kompetisi antar elit (oligarki dikategorikan Buehler sebagai elit) dengan menganalisa kebijakan shari'a yang berpengaruh secara tidak langsung terhadap sumber pendapatan oligarki (Buehler, 2014).

Reklamasi Pantura Jakarta telah banyak diteliti sebelumnya dari perspektif hukum dalam pembuatan kebijakan reklamasi (Rigo \& Qidam, 2020), peranan kelompok masyarakat dalam kebijakan reklamasi (Anam, M Kolopaking, dan A Kinseng 2020; Susanti dan Afrizal 2018) atau manfaat reklamasi terhadap agenda pembangunan berkelanjutan (Rasminto \& Nur, 2018), tanpa menganalisa dominasi oligarki terhadap pembangunan Reklamasi Pantura Jakarta. Adapun studi yang sudah ada hanya mengidentifikasi aktor swasta dan elit pemerintah tanpa menjelaskan dinamika politik keduanya (Royandi \& Keiya, 2019). Sedangkan perspektif analisa konflik seringkali dijelaskan antara elit daerah dan nasional yang berebut kewenangan terkait pembangunan reklamasi (Bintari, 2018; Mutia \& Asteria, 2018). Diantaranya tidak ada yang spesifik mengaitkan pembangunan Reklamasi Pantura Jakarta dengan dominasi oligarki.

Studi Aprelia Amanda, Indiana Ngenget dan Musthopa (2019) menjelaskan reklamasi sebagai kepentingan bisnis, spesifik kepentingan Belanda yang selalu mempengaruhi keputusan. Senada dengan itu, studi yang dilakukan Imam Mahdi (2013) juga menggambarkan konsistensi pembangunan proyek Reklamasi Pantura Jakarta meski mendapat banyak penolakan dari rakyat. Kedua pandangan tersebut (Amanda, Ngenget, \& Makhdor, 2019; Mahdi, 2013) terlalu menyederhanakan fenomena reklamasi mengingat tidak ada penjelasan dinamika antara penguasa dan pengembang sepanjang pembangunan Reklamasi Pantura Jakarta.

Pertarungan antara oligarki dan elit pemerintah di Indonesia dengan cukup detail dan sistematis sehingga dalam analisisnya kerapkali melakukan generalisasi atas dominasi kekuasaan material dari oligarki (Hadiz \& Robison, 2013; Nordholt \& Robison, 1988; Winters, 2011) maupun kekuasaan mobilisasi dari elit pemerintah (Aspinall, 2014; Buehler, 2014). Karena itu, penggunaan kedua sumber kekuasaan tersebut harus dilihat bersamaan dalam satu kasus yang sama untuk menguji dominasi dan daya tahan (durability) dari oligarki dalam menghadapi ancaman. Daya tahan tersebut menurut Winters (2011) yang menjadikan oligarki tetap ada meskipun sistem politik berubah, bahkan pada sistem demokrasi sekalipun oligarki tetap bertahan dengan cara beradaptasi seperti ikut serta dalam kontestasi pemilu dengan membiayai kandidat, mendirikan partai politik, menyewa profesional bahkan menyuap penegakkan hukum. Dinamika antara pengembang dan elit pemerintah tidak dapat dipisahkan dalam menganalisis dominasi oligarki dalam pembangunan Reklamasi Pantai Utara Jakarta.

Kekuasaan oligarki bersumber dari kekayaan atau harta (property) dan pendapatan (income). Dominasi oligarki tidak hanya meliputi akumulasi kekayaan dan pendapatan tetapi juga pertahanan kekayaan dan pendapatan. Jeffrey Winters (Winters, 2011, 2014) secara spesifik menggunakan istilah dominasi material untuk membedakan oligarki dengan elit. Berbeda dengan Hadiz dan Robison (Hadiz \& Robison, 2013) yang memandang oligarki sebagai sebagai sebuah sistem atau tatan akhir dari kapitalisme, Winters (Winters, 2011)

Jurnal Socius: Journal of Sociology Research and Education Vol. 8, No. 1, Th. 2021 
mendefinisikan oligarki sebagai "politik pertahanan kekayaan oleh pelaku yang memiliki kekayaan material". Sedangkan yang dimaksud oligarki adalah "pelaku yang menguasai/memimpin dan mengendalikan konsentrasi besar sumber daya material yang bisa digunakan untuk mempertahankan atau meningkatkan kekayaan pribadi dan posisi sosial ekslusifnya" (Winters, 2011).

Dominasi yang dimaksud Winters merujuk pandangan Foucault (Foucault, 1980) terkait dominasi sebagai bentuk atau model dari relasi kekuasaan antara "dominators" dan "dominated". Dalam hal ini subjek yang didominasi memiliki keterbatasan ruang untuk bermanuver atau menentukan pilihan suatu tindakan. Relasi dominasi pada dasarnya berjalan secara asimetris yang melibatkan aspek penguasaan dan penundukan di dalamnya. Menurut penulis analisa terkait dominasi oligarki perlu dielaborasi lebih lanjut mengingat pengaruhnya terhadap konsentrasi sumber daya alam, pembangunan ekonomi dan pembangunan politik. ikel ini membahas tentang dominasi oligarki dalam pembangunan Reklamasi Pantai Utara, sebagai analisa dipakai teori oligarki dari Jeffrey A. Winters dalam penelitian ini.

\section{Metode Penelitian}

Metode dalam penelitian ini adalah metode kualitatif yaitu menyajikan gambaran spesifik mengenai situasi, penataan sosial atau hubungan (Neuman, 2006). Asumsi penelitian ini berdasarkan paradigma konstruktivisme yakni menganggap setiap individu selalu berusaha memahami dunia di mana mereka hidup dan bekerja (Creswell, 2014). Penelitian ini juga menggunakan dua teknik pengumpulan data yakni data primer melalui wawancara mendalam (indepth interview), dan observasi. Sedangkan untuk data sekunder dilakukan studi literatur yang dapat membantu penulis untuk menguatkan argumen dalam artikel ini, seperti: dokumen pemerintah, hasil riset sebelumnya yang terkait dengan topik dan pemberitaan media massa online.

\section{Hasil dan Pembahasan}

\section{Dominasi Oligarki dalam Pembangunan Reklamasi Pantai Utara Jakarta}

Proyek pembangunan Reklamasi Pantari Utara (Pantura) pada era Orde Baru dilaksanakan berdasarkan Keputusan Presiden Nomor 52 Tahun 1995 yang merupakan tindak lanjut dari Keputusan Presiden sebelumnya No. 17 Tahun 1994 tentang Rencana Pembangunan Lima Tahun Keenam (Repelita VI) periode 1994-1999.

Menurut Keppres 52 tahun 1995 reklamasi merupakan kegiatan penimbunan dan pengeringan laut di bagian perairan laut Jakarta. Wewenang dan tanggung jawab Reklamasi Pantura Jakarta diberikan kepada Gubernur Kepala Daerah Khusus Ibukota Jakarta. Sebagaimana keterangan Bambang Susanto Priyohadi, dirinya mengaku pernah ikut serta memimpin proyek Jabodetabek berdasarkan Intruksi Presiden tahun 1976 untuk membangun kawasan Pantura Jakarta. Awalnya Reklamasi Pantura Jakarta, menurut Bambang, bertujuan untuk merubah daerah kumuh di Jakarta Utara dengan konsep Water Front City yang berbasis pada JMDP (Jabodetabek Metropolitan Development Plan) karena adanya 13 sungai yang mengalir kesana (Wawancara dengan informan, 2020). Keterangan Bambang Susanto menunjukkan bahwa sebelum adanya rancangan 17 pulau seperti saat ini, awalnya reklamasi dimaksudkan untuk pengendalian banjir dengan menggunakan metode polder sytem yakni mengeringkan perairan dan memompa air yang berada di dalam tanggul kedap air untuk dibuang keluar dari daerah lahan reklamasi. Pemerintah saat itu juga mengadakan kerjasama atau $A$ memorandum of understanding (MoU) dengan para pengembang, di antaranya: 
Tabel 1. Pemilik Perusahaan Pengembang Reklamasi tahun 1995

\begin{tabular}{cll}
\hline No & \multicolumn{1}{c}{ Perusahaan } & \multicolumn{1}{c}{ Pemilik } \\
\hline 1 & PT Kapuk Naga Indah & Andree Halim dan Antoni Salim \\
\hline 2 & PT Manggala Krida Yudha & Siti Hutami Endang Adiningsih \\
\hline 3 & PT Pembangunan Jaya Ancol & PT Pembangunan Jaya dan Pemprov DKI Jakarta \\
\hline 4 & PT Dwi Marunda Makmur & $\begin{array}{l}\text { Sudwikatmono, Karman Wijaya, PT Nursalim } \\
\text { Citra Perkasa, Setya Novanto, Bambang Arie } \\
\end{array}$ \\
& & Priambodo, The Nicolas dan The Kwen Le. \\
\hline 5 & BPL Pluit/PT Jakarta Propertindo & Pemprov DKI Jakarta dan PD Pasar Jaya \\
\hline 6 & PT Jaladri KartikaEkapaksi & - \\
\hline 7 & PT Pelindo II & BUMN \\
\hline
\end{tabular}

Sumber: Mimpi Kota Modern Pinggir Laut. Majalah Tempo Edisi 12 Juli Tahun 2010.

Sumber Tempo (Tempo, 2010) tidak menyebutkan pemilik PT Jaladri Kartika Ekapaksi. Namun dalam Kisah Pembangunan Reklamasi Jakarta (Tempo, 2019), Tempo menyebut PT Manggala Krida Yudha dan PT Jaladri Ekapaksi sebagai dua perusahaan yang didirikan khusus oleh Soeharto untuk mengembangkan pulau-pulau reklamasi (Tempo, 2019). Dengan demikian, komposisi pengembang yang terlibat dalam proyek reklamasi dikuasai oleh tiga kelompok yaitu keluarga Presiden Soeharto seperti Mamiek (putri bungsu), Tommy (putra bungsu) dan Sudwikatmono (saudara angkat); Salim Group, yaitu Sudono Salim, anakanaknnya (Andree Halim dan Antoni Salim) serta mitra bisnisnya (Ciputra, PT Nursalim Sinar Perkasa, The Kwen Le), dan; pejabat pemerintah atau birokrat yang saat itu didominasi latar belakang militer seperti Gubernur DKI Jakarta Soerjadi Soedirdja dan Sutioyoso. Pada tahun 1999, Gubernur DKI Jakarta Sutiyoso (periode 1997-2007) mengeluarkan Peraturan Daerah No. 6/1999 Tentang Rencana Tata Ruang Wilayah (RTRW) DKI Jakarta.

Berbeda dengan Peraturan Daerah (Perda) sebelumnya No. 8/1995, Perda baru ini membagi Wilayah Pengembangan Pantai Utara (WP-PU) menjadi dua yakni Pantai Lama dan Pantai Baru sekaligus merubah peruntukan reklamasi dari yang awalnya sekedar pengendalian banjir, kemudian fungsinya bertambah sebagai pelabuhan dan perniagaan (Pantai Baru). Luas dari reklamasi juga disebutkan seluas kurang lebih 2.700 hektar dan diperuntukkan bagi pemukiman masyarakat menengah atas (pasal 32). Proyek Reklamasi Pantura yang digagas pada era kepemimpinan Soeharto tidak dapat dipisahkan dari dominasi pengusaha-pengusaha yang dekat dengan lingkaran kekuasaan.

Selain itu Reklamasi Pantura Jakarta juga bukan proyek reklamasi pertama kali pada era Orde Baru, sebelumnya terdapat empat proyek pembangunan reklamasi yang juga izin pembangunannya diberikan kepada kroni Soeharto dan mayoritas adalah pengusaha keturunan Cina atau Tiongkok. Misalnya Reklamasi Kawasan Pantai Pluit tahun 1970-an oleh PT Dharmala Group yang sekarang menjadi PT. PT Intiland miliki Suhargo Gondokusumo (Go Ka Him), Reklamasi Kawasan Ancol pada tahun 1981 oleh PT Pembangunan Jaya Ancol yang dimiliki Ciputra, Reklamasi di Kawasan Hutan Bakau yang kemudian menjadi Pantai Indah Kapuk (PIK) oleh PT Mandara Permai yang juga dimiliki oleh Ciputra, terakhir Reklamasi di Kawasan Berikat Marunda oleh PT Karya Citra Nusantara yang dimiliki oleh Pemprov DKI Jakarta saat itu. Go Ka Him memiliki koneksi erat dengan Bulog di era Orde Baru serta menjadi satu-satunya importir beras dan gula pada zaman Soeharto (Kunio, 1988). Sedangkan Ciputra (Tjie Siem Hoam) merupakan orang kepercayaan Gubernur DKI Jakarta Ali Sadikin (19661977) dan juga mitra dari Sudono Salim (Liem Sioe Liong) sahabat dari Presiden Soeharto 
sejak masih di Divisi Diponogoro. Keduanya, baik Gondokusumo maupun Ciputra, mendapatkan izin reklamasi karena kedekatan mereka dengan rezim pemerintahan Orde Baru.

Nordholt, Nico G. Schulte, dan Richard Robison (Nordholt \& Robison, 1988) menyebut sejumlah group bisnis besar yang dimiliki China, diantaranya perusahaan yang dimiliki William Soerjadjaja (Tjia Kian Liong), Hanafi (Tan Siong Kie), Dasuhi Angkosubroto (Go Swi Kie), Dharmala Gondokusumo (Go Ka Him), Indra Wijaya, Sjamsul Nursalim, Mochtar Riady dan lain-lain. Menurut Yoshihara Kunio (Kunio, 1988), kapitalis konco atau kroni adalah para pengusaha sektor swasta yang memperoleh keuntungan sangat besar dari hubungan eratnya dengan kepala negara atau dalam hal ini Presiden Soeharto. Dua nama yang kerapkali dihubungkan dengan Presiden Soeharto adalah Liem Sioe Liong (Sudono Salim) dan Bob Hasan. Keduanya merupakan rekan bisnis Soeharto sebelum menjadi Presiden atau semasa Soeharto memimpin Divisi Diponogoro, keduanya Menurut George Aditjondro (Aditjondro, 2006) "memasok apa saja yang diperlukan oleh Komandan Diponogoro untuk tentaranya, dari beras, seragam hingga obat-obatan.”.

Hubungan antara pengusaha Cina dan militer pada era Orde Baru, sebagaimana digambarkan oleh Winters (Winters, 2011), cukup dekat yaitu dengan memberikan bagianbagian tertentu dari pasar Indonesia kepada pengusaha keturunan Cina dengan syarat memiliki mitra komandan militer untuk memperkaya diri, dan akhirnya Soeharto mengendalikan semua komando militer penting dalam Angkatan Darat pada tahun 1969. Senada dengan Winters, studi Nur Khairunnisa Sugiarto (Sugiarto, 2018) memandang peranan Dwi Fungsi ABRI era Orde Baru membuat profesionalisme militer Indonesia mengalami penurunan, karena militer tidak lagi hanya sebagai tentara penjaga kemanan negara tetapi juga sebagai pelaku bi snis atau menjadi komisariat perusahaan-perusahaan besar. Kolaborasi antara keduanya serta perlindungan dari rezim Soeharto berhasil mendominasi pengelolaan dan penguasaan sumber daya alam di Indonesia, tidak terkecuali dengan reklamasi yang menghasilkan keuntungan besar dalam pembangunannya. Dengan kata lain dominasi oligarki dalam pembangunan reklamasi merupakan konsekuensi atau salah satu bentuk dari dominasi oligarki terhadap pengelolaan dan penguasaan sumber daya alam di Indonesia. Tetapi meski demikian, uraian di atas juga menegaskan tipologi Winters (Winters, 2011) terkait "oligarki sultanistik" dimana Presiden Soeharto menjadi “dominator" yang menjinakkan oligarki, spesifik pengusaha Cina (dominated).

Krisis finansial Asia pada tahun 1997 selain mendorong reformasi politik pada tahun 1998 juga mengakibatkan liberalisasi ekonomi. Pemerintah kemudian membentuk BPPN (Badan Penyehatan Perbankan Nasional), setidaknya 108 perusahaan yang terkoneksi dengan bisnis Salim Group diserahkan kepada BPPN untuk dijual di pasar saham luar negeri. Selain Salim Group, sejumlah perusahaan yang dimiliki oleh militer dan keluarga Soeharto juga terkena dampaknya dan beralih kepemilikan tidak terkecuali dengan perusahaan pengembang reklamasi Pantura yang juga mengalami perubahan, berikut penulis mencatat sejumlah peralihan kepemilikan perusahaan pengembang reklamasi sebelum dan sesudah krisis 1997:

Tabel 2. Peralihan Kepemilikan Perusahaan Pengembang Reklamasi Pantura Jakarta sebelum dan sesudah Krisis 1997

\begin{tabular}{clll}
\hline No & \multicolumn{1}{c}{ Perusahaan } & \multicolumn{1}{c}{ Pemilik Lama } & \multicolumn{1}{c}{ Pemilik Baru } \\
\hline 1 & PT Kapuk Naga & Andree Halim dan Antoni & $\begin{array}{l}\text { Agung Sedayu Group (Sugianto } \\
\text { Susuma) }\end{array}$ \\
& Indah & Salim & Sudjono (Direktur Utama) \\
\hline 2 & PT Manggala & Siti Hutami Endang & \\
& Krida Yudha & Adiningsih (Mamiek) & \\
\hline
\end{tabular}

Jurnal Socius: Journal of Sociology Research and Education Vol. 8, No. 1, Th. 2021 
Luthfi Hasanal Bolqiah, Riaty Raffiuddin Dominasi Oligarki dalam Pembangunan Reklamasi Pantai Utara Jakarta

\begin{tabular}{clll}
\hline 3 & $\begin{array}{l}\text { PT Pembangunan } \\
\text { Jaya }\end{array}$ & $\begin{array}{l}\text { Ciputra dan Pemprov DKI } \\
\text { Jakarta }\end{array}$ & Pemprov DKI Jakarta \\
\hline 4 & $\begin{array}{l}\text { PT. Muara } \\
\text { Wisesa Indah }\end{array}$ & $\begin{array}{l}\text { Hutomo Manda Putra } \\
\text { (Tommy) dan Siti Hutami } \\
\text { Endang Adiningsih (Mamiek) }\end{array}$ & $\begin{array}{l}\text { Agung Podomoro Land (Tri } \\
\text { Hatma Kusuma Halim) }\end{array}$ \\
\hline 5 & $\begin{array}{l}\text { PT. Taman } \\
\text { Harapan Indah }\end{array}$ & $\begin{array}{l}\text { Dharmala Group } \\
\text { PT. Intiland Development } \\
\text { (Hendro Santoso Gondokusumo) }\end{array}$ \\
\hline 6 & $\begin{array}{l}\text { PT Jaladri Kartika } \\
\text { Ekapaksi }\end{array}$ & $\begin{array}{l}\text { Hutomo Manda Putra } \\
\text { (Tommy) dan Siti Hutami } \\
\text { Endang Adiningsih (Mamiek) }\end{array}$ & Tri Hatma Kusuma Halim \\
\hline
\end{tabular}

Sumber: Disusun oleh penulis berdasarkan Majalah Tempo Edisi 12 Juli Tahun 2010 dan "Kisah Pembangunan Reklamasi", (2019), Tempo Publishing.

Berdasarkan Tabel 2 perubahan kepemilikan antara sebelum dan sesudah krisis 1997 pada dasarnya tidak menghadirkan aktor baru dalam pembangunan Reklamasi Pantura atau dengan kata lain masih didominasi oleh oligarki Cina, yaitu Sugianto Kusuma (Aguan), Tri Hatma Kusuma Halim dan Hendro Santoso Gondokusumo. Ketiga aktor tersebut juga pada dasarnya terikat dengan rezim Orde Baru, misalnya PT. Kapuk Naga Indah yang awalnya dimiliki oleh kakak beradik Andree Halim dan Antoni Salim (anak dari Sudono Salim/Liem Sioe Liong), setelah reformasi, berada dibawah PT Agung Sedayu Group (ASG) yang dimiliki oleh Sugianto Kusuma (Aguan) yang sebelumnya dimiliki oleh Tommy Winata. Aguan sendiri sebenarnya sudah masuk ke lingkaran bisnis Orde Baru sejak tahun 1986 seiring dengan restrukturisasi Propelat (Proyek Perhotelan Angkatan Darat). Bersama-sama dengan Tommy Soeharto, Aguan mendapat 30\% saham Propelat yang kemudian berubah menjadi Bank Artha Graha (Matanasi, 2019). ASG juga merupakan bagian dari Yayasan Kartika Eka Paksi (YKEP) yang juga bagian dari bisnis militer. Propelat dan Yayasan Kartika Eka Paksi saat itu dipimpin oleh Jendral Edi Sudrajat yang akrab dengan Tommy Winata. Tommy yang awalnya hanya memiliki saham 30\% akhirnya menguasai Propelat dan merubahnya menjadi Bank Artha Graha sebelum akhirnya dikuasai oleh Aguan. PT Kapuk Naga Indah sendiri memegang izin pembangunan atas lima pulau reklamasi yakni A, B, C, D dan E.

Adapun Tri Hatma Kusuma Salim adalah rekan Aguan dan pernah memiliki sejumlah proyek bersama seperti Kawasan Kelapa Gading dan Mangga Dua Square (Tempo, 2019). Ayah dari Tri Hatma Haliman yaitu Anton Haliman mendirikan Agung Podomoro Land (APL) tahun 1969 bersama dengan Salimin Prawiro Sumatro (Mentri Perhubungan tahun 1967-1968). Salimin juga sering bermitra dengan Tommy Soeharto, salah satunya adalah perumahan Sentul City oleh PT Bukit Sentul atau yang sekarang disebut PT Sentul City Tbk (Alexander, 2016). APL awalnya bernaung di bawah induk PT Sunter Agung yang seiring masalah keuangan saat krisis APL akhirnya mengambil alih beberapa pengembang properti di kawasan Sunter, Jakarta. Pada proyek Reklamasi Pantura Jakarta, APL memiliki izin pembangunan atas tiga pulau, masing-masing oleh anak perusahannya yaitu Pulau F oleh PT Agung Dinamika Perkasa, Pulau G oleh PT Muara Wisesa Samudra dan Pulau I oleh PT Jaladri Kartika Eka Pakci. Sedangkan PT Intiland yang dimiliki oleh Hendro Santoso Gondokusumo memiliki izin pembangunan terhadap pulau H. Dengan demikian, ketiga aktor tersebut pada dasarnya bukan aktor baru pasca reformasi. Ketiganya masih memiliki koneksi dengan rezim bisnis Orde Baru dan juga merupakan pengusaha keturunan Cina. Artinya dari 17 pulau yang akan dibangun, 9 diantaranya izinnya dimiliki oleh oligarki Cina.

Dominasi oligarki pasca reformasi berbeda dengan sebelumnya pada masa Orde Baru, dimana para oligarki di era Orde Baru cukup memiliki kedekatan dengan keluarga Suharto

Jurnal Socius: Journal of Sociology Research and Education Vol. 8, No. 1, Th. 2021 
ataupun para petinggi militer. Sedangkan pasca reformasi, dampak dari pelaksanaan demokrasi elektoral masing-masing oligarki dituntut untuk memiliki relasi dengan pejabat pemerintah. Pendapatan oligarki tidak lagi ditentukan dengan kedekatannya bersama militer tetapi justru kedekatannya dengan gubernur terpilih. Pertahanan pendapatan, sebagaimana yang dikemukakan oleh Winters (Winters, 2011), memaksa oligarki untuk menggunakan keuntungannya demi mempertahankan sumber pendapatan atau keuntungannya yang lain yakni dengan cara terlibat dalam politik. Oligarki mulai dengan mensponsori para kandidat dalam pemilihan umum baik pada pemilu nasonal (Ma'mun \& Kosandi, 2020) maupun pemilu daerah (Nge, 2018) bahkan sampai ikut mendirikan partai politik (Mietzner, 2014).

Pada kasus reklamasi relasi oligarki dengan Gubernur Basuki Tjahaja Purnama (BTP) merupakan yang paling jelas terlihat. Hasil Investigasi Jurnalis Detik (Hikmat, Durahman, \& Bhawono, 2016) ketika BTP masih menjabat sebagai Wakil Gubernur DKI Jakarta tahun 2014, BTP menghadiri penandatangan kewajiban tambahan kontribusi bagi perusahaan pengembang reklamasi Pantura Jakarta yang digelar di ruang rapat Balai Kota DKI Jakarta. Dalam rapat tersebut BTP mengatakan "kalau ini diberesi, 2017 tidak usah kasih duit kita kampanye, pak" pernyataan tersebut disambung oleh Ariesman Widjaja, Direktur Utama PT Muara Wisesa Samudra, "Asyik... enggak usah. Ini saja sumbangan saya, ya, pak. Sudah jadi langsung, ya". Selain PT Muara Wisesa Samudra, pengembang yang hadir dalam rapat tersebut adalah PT Jaladri Kartika Ekapaksi dan PT Taman Harapan Indah. Terkait hal ini, BTP dapat dikategorikan sebagai politisi yang menjalankan bisnis untuk membiayai operasi politik mereka (Mietzner, 2014).

Pada kasus reklamasi, pertahanan oligarki terlihat dalam peralihan kepemilikan perusahaan pengembang reklamasi dan kedekatannya dengan elit pemerintah daerah. Berbeda halnya dengan asumsi Winters, penulis melihat upaya dari oligarki untuk mengakumulasi keuntungan dengan mengambil alih perusahaan yang sebelumnya telah memiliki izin pembangunan dan kemudian barulah setelah itu mempertahankannya. Dengan kata lain, individu yang memiliki sumber daya utama berupa kepemilikan pribadi dan langsung atas modal dalam jumlah besar (Mietzner, 2014). Definisi Mietzner lebih relevan pada kasus Reklamasi Pantai Utara Jakarta karena oligarki bukanlah individu yang sejak awal sudah kaya dan berkuasa dan mempertahankan kekayaannya seperti yang dikemukakan Winters (Winters, 2011), melainkan individu yang menambah kekayaan dan kekuasaannya pada saat bersamaan. Meskipun keterlibatan oligarki dalam politik dapat juga sebagai metode pertahanan (wealth defence) oligarki namun tindakan Aguan dan Tri Hatma lebih merupakan bentuk dominasi atau penguasaan ketika terlibat dalam pembangunan reklamasi. Selain itu, kerangka teoritis Mietzner dapat lebih menggambarkan relasi antara elit pemerintah dan oligarki sebagaimana kasus di atas antara BTP dan para pengembang. Oleh karenanya, sepakat dengan Mietzner (Mietzner, 2014) bahwa terlalu cepat untuk mendeklarasikan kemenangan oligarki (prematurely declare victory of the oligarchic force) sebagaimana pada bagian berikutnya dominasi oligarki akan diuji dengan serangkaian ancaman dari elit pemerintah yaitu kementrian dan kepala daerah dalam pembangunan Reklamasi Pantura Jakarta.

\section{Ancaman terhadap Dominasi Oligarki dalam Pembangunan Reklamasi Pantai Utara Jakarta}

Ancaman kementrian terhadap dominasi oligarki terjadi dua kali pada tahun 2003 dan 2016. Pada tahun 2003, Mentri Lingkungan Hidup Nabil Makarim menerbitkan Surat Keputusan (SK) No. 14/2003 tentang Ketidaklayakan Rencana Kegiatan Reklamasi dan Revitalisasi Pantai Utara Jakarta, sedangkan pada tahun 2016 terjadi saat Mentri Koordinator Bidang Kemaritiman Rizal Ramli bersama-sama dengan Mentri Lingkungan Hidup dan 
Kehutanan Siti Nurbaya dan Mentri Kelautan dan Perikanan Susi Pudjiastuti menghentikan sementara (moratorium) pembangunan Reklamasi Pantura Jakarta. Adapun dasar dari penerbitan SK No. 14/2003, menurut Mentri Nabiel Makarim dikarenakan dampak buruk reklamasi terhadap lingkungan juga memiliki dampak sosial yang tidak kecil. Selain pengaruhnya terhadap lingkungan, menurut Menteri Nabiel, reklamasi juga berdampak pada mata pencaharian nelayan. Bahkan lebih dari itu, reklamasi juga memberikan dampak sosialnya yaitu enclave, "Satu etnis tertentu di satu tempat tertutup dipisahkan air, ada pembatasnya, enggak baik." (Handayani, 2016).

Ancaman berikutnya terhadap dominasi oligarki dalam pembangunan reklamasi juga muncul dari Gubernur DKI Jakarta Basuki Tjahaja Purnama (BTP) dan Gubernur setelahnya Anies Baswedan. Berbeda dengan ancaman kementrian yang berusaha menghentikan reklamasi, ancaman dari Gubernur BTP berupa kebijakan redistribusi yakni meminta tambahan kontribusi kepada pengembang senilai 15\% Nilai Jual Objek Pajak (NJOP) dari total lahan yang dapat dijual. Menurut BTP, dari tambahan kontribusi itu dapat dipakai buat pembangunan dan dalam 10 tahun DKI akan mendapatkan total 158 Triliun. Hal itu disampaikan dalam debat putaran kedua Pilkada DKI Jakarta tahun 2017 (Youtube Mata Najwa, 2017). Adapun perizinan yang diberikan BTP kepada pengembang juga mensyaratkan agar pengembang sebelumnya melaksanakan kewajibannya seperti pembangunan rusun. Tetapi BTP membedakan perlakuannya antara perusahaan swasta dan BUMD, khusus untuk BUMD seperti PT Propertindo tidak diminta kontribusi. Menurut BTP (Youtube Kompas TV, 2016) selama BUMD bisa menimbun (reklamasi) dan bisa menjualnya maka dipersilahkan membangun.

Berbeda dengan kebijakan BTP, gubernur terpilih Anies Baswedan mengancam dominasi oligarki dengan mencabut izin 13 pulau reklamasi. Dasar argumentasi Anies sebenarnya tidaklah baru, pendekatan yang dimaksud Anies juga digunakan oleh Menteri KLH Nabil Makarim dan Menko Maritim Rizal Ramli sebelumnya, bahkan BTP sendiri pernah menegur pengembang dengan pendekatan serupa pada tahun 2016 yakni ekslusifitas (Rudi, 2016). Kemenangan Anies-Sandi di Pilkada DKI Jakarta tahun 2017 juga tidak bisa dilepaskan dari peranan kelompok nelayan, misalnya Komunitas Nelayan Tradisional Muara Angke dan Paguyuban Nelayan Kepulauan Seribu. Ketika Kampanye pasangan Anies-Sandi mengidentifikasi dirinya dengan kelompok nelayan sebagai bagian dari keberpihakannya terhadap masyarakat bawah. Menurut Anies pemukiman mewah yang akan dibangun pasti tidak akan dimiliki oleh nelayan, nelayan menurutnya hanya bisa menonton dari jauh pulau reklamasi (Youtube CNN Indonesia, 2017). Bahkan satu hari setelah pelantikan Anies-Sandi menjadi Gubernur dan Wakil Gubernur DKI Jakarta tahun 2017-2022, dalam pidato politiknya di Balai Kota DKI Jakarta, Senin malam tanggal 16 Oktober 2017 Anies menegaskan konsistensinya untuk menghentikan reklamasi Pantura Jakarta.

Perbedaan tindakan elit pemerintah menunjukan ragam penggunaan kekuasaan. Pada saat BTP menjabat sebagai Gubernur DKI Jakarta, Joko Widodo menjadi Presiden Indonesia terpilih dalam pemilu 2014 dan para pengembang ikut terlibat membantu kemenangan Joko Widodo (Winarno, 2016) maka pada ancaman BTP bukanlah penghentian tetapi tuntutan untuk menambah pemasukan daerah. Senada dengan itu, studi Abdul Rahman Ma'Mun dan Meidi Kosandi (Ma'mun \& Kosandi, 2020) menyimpulkan bahwa komposisi terbesar (80\%) sumbangan dana kampanye Jokowi-Ma'ruf sebagai pemenang Pilpres 2019 adalah berasal dari kelompok dan perusahaan yang sebagian merupakan oligarki. Sedangkan pada masa Anies Baswedan menjadi gubernur, rezim provinsi tidak sejalan dengan rezim nasional. Perbedaan rezim tersebut membuat Anies tidak memiliki pilihan lain untuk merealisasikan janjinya selain dengan menggunakan keputusan gubernur dan merujuk pada kepres 52/1995.

Jurnal Socius: Journal of Sociology Research and Education Vol. 8, No. 1, Th. 2021 


\section{Dampak Kebijakan Elit Pemerintah terhadap Dominasi Oligarki}

Dominasi oligarki terhadap kebijakan dan hasil politik, menurut Pepinsky (2014) tidak dapat dijelaskan hanya dengan tipologi oligarki sebagaimana yang dikemukakan Winters (2011). Melainkan dengan memposisikan oligarki berhadapan dengan ancamannya, terutama ancaman atau counter-oligarch agenda yang berasal dari elit pemerintah. Pada kasus reklamasi Pantai Utara (Pantura) Jakarta kebijakan pencabutan izin 13 pulau oleh Gubernur DKI Jakarta Anies Baswedan digugat empat pengembang. Oleh karena itu, dalam melakukan analisis pertarungan oligarki dan elit pemerintah menurut Pepinsky (2014) dengan cara menetapkan ex-ante faktor penentu jenis koalisi dan konsekuensi politik koalisi terhadap kebijakan dan hasil politik (outcomes policies).

Sebuah kebijakan memiliki implikasi distribusional yang pada akhirnya memecah kaum oligarki dan mencipta kepentingan bersama di antara kaum oligarki dengan aktor-aktor yang mememiliki kekayaan lumayan besar. Perpecahan atau konflik distribusional tersebut terjadi karena para oligarki dan pengusaha kecil sama-sama berusaha menghindar dari kebangkrutan (Pepinsky, 2014). Salah satu dampak dari kebijakan politik terhadap pengembang dapat dilihat dari harga saham. Misalnya pada kasus dugaan suap dalam pembahasan rancangan peraturan daerah (Raperda) reklamasi Teluk Jakarta, tidak hanya menyeret nama Presiden Direktur PT Agung Podomoro Land Tbk Ariesman Widjaja. Kasus tersebut juga membuat harga saham raksasa perusahaan properti itu anjlok cukup dalam.

Dampak kebijakan penghentian 13 pulau reklamasi juga dapat dilihat dari kerugian yang diterima pengembang. Menurut Agung Praptono, sekretaris perusahaan Pembangunan Jaya Ancol, mengakui ada biaya yang sudah dikeluarkan perseroan dalam proyek reklamasi itu. Sejak 2010 hingga Juni 2016, Ancol mengeluarkan dana untuk reklamasi sebesar Rp470,29 miliar, dan dicatat sebagai aset dalam penyelesaian di pos aset tetap (Kumparan, 2018).

Respon para pengembang juga beragam, sebagaimana kebijakan elit pemerintah. Menanggapi ancaman dari kementrian Lingkungan Hidup tahun 2003 dan kebijakan pencabutan izin 13 pulau reklamasi, para pengembang sama-sama melakukan gugatan. Sedangkan pada menghadapi ancaman BTP terkait tambahan kontribusi, respon pengembang justru melakukan upaya suap terhadap anggota DPRD DKI Jakarta Muhammad Sanusi.

Berbeda lagi dengan respon terhadap moratorium reklamasi oleh Menko Rizal Ramli dimana para pengembang menggunakan kedekatannya dengan rezim nasional untuk menghilangkan ancaman dari Rizal Ramli. Ragam respon pengembang dalam hal ini selain menegaskan klaim Winters terkait metode pertahanan kekayaan dari oligarki juga menegaskan peranan kebijakan atau hasil politik dalam mengancam dominasi reklamasi sebagaimana dikemukakan Pepinsky (Pepinsky, 2014).

Adapun terkait efektifitas ancaman tersebut penulis melihat kebijakan Anies Baswedan memiliki potensi yang jauh lebih besar dan kuat dalam mengancam dominasi oligarki atau spesifik sumber pendapatan oligarki yakni keuntungan dari hasil pembangunan reklamasi. Sebaliknya, implikasi distribusional dari kebijakan Anies justru malah memecah dominasi oligarki atau speifik kepentingan para pengembang. Praktis potensi gugatan dari para pengembang pada atas kebijakan Anies lebih lemah dibanding sebelumnya. Perpecahaan diantara oligarki atau para pengembang juga sangat seringkali terjadi menurut Pepinsky dikarenakan baik oligarki maupun pengusaha kecil pada dasarnya sama-sama akan berusaha untuk menghindar dari kebangkrutan. 


\section{Simpulan}

Penelitian ini menunjukkan bahwa dominasi oligarki dimulai pada pembangunan Reklamasi Pantai pantura sejak dari era kepemimpinan Soeharto. Sedangkan pada masa reformasi, oligarki menjali hubungan dengan kepala daerah atau dalam hal ini Gubernur DKI Jakarta untuk mempertahankan dominasi oligarki. Namun selain itu, terdapat juga oligarki atau aktor lain yang ikut serta pada masa reformasi dengan mengambil alih perusahaan yang sebelumnya sudah mendapatkan izin pembangunan. Artinya oligarki tidak hanya mempertahankan kekayaan dan pendapatannya sebagaimana menurut Winters (2011), dominasi oligarki dalam reklamasi Pantura Jakarta juga memperlihatkan akumulasi kekayaan dan pendapatan. Kebijakan penghentian reklamasi oleh Gubernur DKI Jakarta Anies Baswedan menimbulkan kerugian terhadap sumber pendapatan oligarki sebagaimana juga dilakukan oleh elit pemerintah sebelumnya tetapi lebih efektif. Efektifitas tersebut terlihat dari strategi penyesuaian kebijakan dengan aturan-aturan yang ada sehingga kebijakannya kuat di pengadilan dan politik distribusional yang memecah respon pengembang meskipun sebelumnya bersatu dalam Paguyuban Pengembang.

\section{Referensi}

Aditjondro, G. J. (2006). Korupsi Kepresidenan: Reproduksi Oligarki Berkaki Tiga: Istana, Tangsi, dan Partai Penguasa. Jakarta: LKiS.

Alexander, H. B. (2016). Mochtar Riady: Saya Diminta Ikut Bereskan Proyek Anak "Babe." Retrieved from https://properti.kompas.com/read/2016/01/27/070000121/Mochtar.Riady.Saya.Diminta. Ikut.Bereskan.Proyek.Anak.Babe.?page=all

Amanda, A., Ngenget, I., \& Makhdor, M. (2019). Kebijakan Gubernur Basuki Tjahaja Purnama dalam Reklamasi Pantai Utara Tahun 2014-2017. Jurnal ISIP: Jurnal Ilmu Sosial Dan Ilmu Politik, 16(2), 105-108. https://doi.org/10.36451/j.isip.v16i2.29

Anam, K., M Kolopaking, L., \& A Kinseng, R. (2020). The Effectiveness of Social Media Usage within Social Movement to Reject the Reclamation of the Jakarta Bay, Indonesia. Sodality: Jurnal Sosiologi Pedesaan, 8(1), 64-81. https://doi.org/10.22500/8202028955

Aspinall, E. (2014). Popular agency and interests in Indonesia's democratic transition and consolidation. In M. Ford \& T. B. Pepinsky (Eds.), Beyound Oligarch: Wealth, Power and Contemporary Indonesian Politics (pp. 117-13). Ithaca, NY: Cornell Southeast Asia Program Publications. https://doi.org/10.5728/indonesia.96.0011

Bachtiar, Bolqiah, L. H., \& Andrean, S. (2020). Menguatnya Partai Politik Kartel Pada Pemilu Serentak 2019. Jurnal Pengawasan Pemilu Provinsi DKI Jakarta, 1(1), 73-92.

Barbier, E. B. (2003). The Role of Natural Resources in Economic Development. Australian Economic Papers, 42(2), 253-272. https://doi.org/10.1111/1467-8454.00198

Beblawi, H., \& Luciani, G. (2015). The rentier state. In The Rentier State. https://doi.org/10.4324/9781315684864

Bintari, A. (2018). Manajemen Konflik Penyelesaian Kasus Reklamasi Pulau G Pantai Utara Jakarta. CosmoGov, 4(1), 119-144. https://doi.org/10.24198/cosmogov.v4i1.18212

Buehler, M. (2014). Elite Competition and Changing State-Society Relations: Shari'a Policymaking in Indonesia. In M. Ford \& T. B. Pepinsky (Eds.), Beyond Oligarchy: Wealth, Power and Contemporary Indonesian Politics (pp. 157-176). Ithaca, NY: Cornel Southeast Asia Program Publications. https://doi.org/10.7591/9781501719158-011 
CNN Indonesia. (2018). Total 326 Orang Jadi Tersangka Korupsi SDA Selama 2010-2017. Retrieved from https://www.cnnindonesia.com/nasional/20180427144107-20294128/total-326-orang-jadi-tersangka-korupsi-sda-selama-2010-2017

Creswell, J. (2014). Research Design, Qualitative, Quantitative and Mixed Methodes Approach (4th ed.). United States of America: SAGE Publication.

Foucault, M. (1980). Oligarki Partai Politik Dalam Rekrutmen Calon Kepala Daerah. In New York. New York: Pantheon Books. https://doi.org/citeulike-article-id:798470

Hadiz, V. R., \& Robison, R. (2013). The political economy of oligarchy and the reorganization of power in Indonesia. Indonesia. https://doi.org/10.5728/indonesia.96.0033

Handayani, M. S. (2016). Tanpa Amdal Menyeluruh, Reklamasi Melanggar Hukum. Retrieved from https://tirto.id/tanpa-amdal-menyeluruh-reklamasi-melanggar-hukum-bKWR

Hikmat, I., Durahman, I., \& Bhawono, A. (2016). Kisah "Perjanjian Preman" Ahok. Retrieved from Detik website: https://news.detik.com/x/detail/investigasi/20160530/DealReklamasi-di-Pulau-Hengky/

Huntington, S. P., \& Fukuyama, F. (2006). Political order in changing societies. In Political Order in Changing Societies. New Heaven: Yale University Press. https://doi.org/10.5771/0506-7286-1970-2-257

KPK RI. (2019). Nota Sintesis : Evaluasi Gerakan Nasional Penyelamatan Sumber Daya Alam 2018.

Kumparan. (2018). Anies Minta HGB Pulau Reklamasi Dibatalkan, Saham APLN Anjlok. Retrieved from https://kumparan.com/kumparanbisnis/anies-minta-hgb-pulaureklamasi-dibatalkan-saham-apln-anjlok/full

Kunio, Y. (1988). The Rise of Ersazt Capitalism in Southeast Asian. Singapore: Oxford University Press.

Ma'mun, A. R., \& Kosandi, M. (2020). The Politics of Campaign Funding in The Presidential Election 2019. Literatus, 2(2), 162-180. https://doi.org/https://doi.org/10.37010/ lit.v2i2.93

Mahdi, I. (2013). Reklamasi Teluk Jakarta Sebuah Prespektif Kekuasaan Dalam Ekonomi Politik. Jurnal Transformasi Global, 4(1), 38-45.

Matanasi, P. (2019). Sejarah Persinggungan Tommy Winata dengan Tentara. Retrieved from Tirto website: https://tirto.id/sejarah-persinggungan-tommy-winata-dengan-tentara-ee2a

Meadows, D. H., Meadows, D. L., Randers, J., \& Behrens, W. W. (1972). The Limits to Growth. Washington, DC: Universe Books.

Mietzner, M. (2014). Oligarchs, Politicians, and Activists: Contesting Party Politics in PostSuharto Indonesia. In Beyond Oligarchy: Wealth, Power and Contemporary Indonesian Politics (pp. 99-116). Ithaca, NY: Cornel Southeast Asia Program Publications. https://doi.org/10.7591/9781501719158-008

Migdal, J. S. (1988). Vision and Practice: The Leader, the State, and the Transformation of Society. International Political Science Review, 9(1), 23-41. https://doi.org/10.1177/019251218800900103

Mutia, E. F., \& Asteria, D. (2018). Jakarta Bay reclamation policy: An analysis of political ecology. E3S Web of Conferences. Sarawak, Malaysia: EDP Sciences. https://doi.org/10.1051/e3sconf/20185200014

Neuman, W. L. (2006). Social Research Method: Qualitative and Quantitative Approach, Sixth Edition. jakarta: Index.

Nge, H. J. (2018). Oligarki Partai Politik Dalam Rekrutmen Calon Kepala Daerah. Jurnal Academia Praja, 1(1), 59-84. https://doi.org/10.36859/jap.v1i01.42

Nordholt, N. G. S., \& Robison, R. (1988). Indonesia: The Rise of Capital. Pacific Affairs, 61(2),

Jurnal Socius: Journal of Sociology Research and Education Vol. 8, No. 1, Th. 2021 
375. https://doi.org/10.2307/2759350

Pepinsky, T. B. (2014). Pluralism and political conflict in Indonesia. In Beyound Oligarch: Wealth, Power and Contemporary Indonesian Politics (pp. 79-98). Ithaca, NY: Cornel Southeast Asia Program Publications. https://doi.org/10.5728/indonesia.96.0079

Pye, L. W. (1966). Aspects of Political Development. Boston \& Toronto: Little, Brown and Company. https://doi.org/10.2307/40184477

Rasminto, \& Nur, S. (2018). Studi Reklamasi Teluk Jakarta Di Pulau C Dan D Dalam Perspektif Pembangunan Berkelanjutan Dan Nilai-Nilai Pancasila. Jurnal Geografi Edukasi Dan Lingkungan, 2(2), 102-110.

Rigo, I. D., \& Qidam, A. (2020). Aspek Hukum Tentang Pemberian Izin Kegiatan Reklamasi Pantai Utara Jakarta. Jurnal Hukum Magnum Opus, 3(1), 102-112. https://doi.org/10.30996/jhmo.v3i1.3086

Robison, R. (1986). The Rise of Capital (13th ed.). Sydney: Allen and Unwin.

Royandi, E., \& Keiya, R. (2019). Kontestasi Aktor Dalam Pengelolaan Sumber Daya Pesisir Di Wilayah Pembangunan Reklamasi Teluk Jakarta. Temali : Jurnal Pembangunan Sosial, 2(1), 77-98. https://doi.org/10.15575/jt.v2i1.3619

Rudi, A. (2016). Ahok: Pulau Reklamasi Jangan Cuma Diisi Orang Kaya.

Sidel, J. T. (2004). Bossism and democracy in the Philippines, Thailand, and Indonesia. Politicising Democracy: The New Local Politics and Democratisation.

Sugiarto, N. K. (2018). Bisnis Militer Pasca Orde Baru. CosmoGov, 4(2), 237-246. https://doi.org/10.24198/cosmogov.v4i2.17064

Susanti, N., \& Afrizal, A. (2018). Upaya Greeanpeace Menjaga Kawasan Pantai Indonesia Terkait Proyek Pulau Reklamasi Teluk Jakarta. Jurnal Online Mahasiswa Fakultas Ilmu Sosial Dan Ilmu Politik Universitas Riau, 5(1), 1-18.

Syarif, M. L., \& Faisal. (2019). Addressing the Root of Political Corruption in Indonesia. Jurnal Antikorupsi Integritas, 5(2), 191-198. https://doi.org/https://doi.org/10.32697/integritas.v5i2.487

Tempo. (2010). Mimpi Kota Modern Pinggir Laut. Retrieved from Tempo website: https://majalah.tempo.co/read/arsitektur/134021/mimpi-kota-modern-pinggir-laut

Tempo. (2019). Kisah Pembangunan Reklamasi Jakarta. Tempo Publishing.

Umam, A. K. (2019). Lemahnya Komitmen Antikorupsi Presiden di Antara Ekspektasi Pembangunan Ekonomi dan Tekanan Oligarki. Jurnal Antikorupsi Integritas, 5(2), 1-17.

Winarno, H. H. (2016). Adhie Massardi: Ahok kongkalikong dengan pengembang tumbangkan Rizal. Retrieved from https://www.merdeka.com/peristiwa/adhie-massardi-ahokkongkalikong-dengan-pengembang-tumbangkan-rizal.html

Winters, J. A. (2011). Oligarchy. New York: Cambridge University Press. https://doi.org/10.1017/CBO9780511793806

Winters, J. A. (2014). Oligarchy and democracy in Indonesia. In M. Ford \& T. B. Pepinsky (Eds.), Beyond Oligarchy: Wealth, Power and Contemporary Indonesian Politics (pp. 11-34). Ithaca, NY: Cornel Southeast Asia Program Publications. https://doi.org/10.5728/indonesia.96.0099

Youtube CNN Indonesia. (2017). Debat Final Pilkada DKI Putaran Kedua; Ahok-Djarot \& Anies-Sandi.

Youtube Kompas TV. (2016). Ahok Bersaksi di Tipikor (Breaking News). In Youtube Kompas $T V$.

Youtube Mata Najwa. (2017). Ekslusif 2017: Babak Final Pilkada DKI Jakarta. In Youtube Mata Najwa.

Jurnal Socius: Journal of Sociology Research and Education Vol. 8, No. 1, Th. 2021 